\title{
Acute occlusion of the ductus pancreaticus due to abdominal aortic aneurysm: Uncommon cause of silent severe acute pancreatitis - a case report and review of the literature
}

\author{
Helmut Raphael Lieder ${ }^{1,2}$, Matthias Buechter ${ }^{1}$, Johannes Grueneisen ${ }^{3}$, Guido Gerken ${ }^{1}$, Ali Canbay ${ }^{1}$, Alisan Kahraman*1 \\ ${ }^{1}$ Department of Gastroenterology and Hepatology, University Hospital Essen, Germany \\ ${ }^{2}$ Department of Thoracic and Cardiovascular Surgery, West German Heart Center Essen, University Hospital Essen, Germany \\ ${ }^{3}$ Department of Radiology, University Hospital Essen, Germany
}

Received: October 13, 2015

DOI: $10.5430 /$ crim.v3n1p38
Accepted: December 9, 2015 Online Published: December 22, 2015

URL: http://dx.doi.org/10.5430/crim.v3n1p38

\begin{abstract}
We report an uncommon case of severe silent acute pancreatitis (SSAP) caused by compression of the Ductus pancreaticus due to an abdominal aortic aneurysm (AAA) of $79 \mathrm{~mm} \times 59 \mathrm{~mm}$ external diameter. A 78-year-old patient with known cutaneous progressive T-cell lymphoma and hypertension was referred to our institution in August 2013. During hospitalisation the patient became somnolent and developed elevated infection parameters. Abdominal ultrasonography showed a pulsating abdominal mass and CT examination revealed a stretched pancreas and an underlying partial thrombosed juxtarenal AAA extending distally to the origin of the superior mesenteric artery (SMA) and the aortic bifurcation without signs of visceral malperfusion elsewhere. The Ductus pancreaticus was dilated without involvement of the head. There were no additional radiological findings of occupying character other than the AAA. Because of his advanced age, increasing inflammatory parameters, and cutaneous T-cell lymphoma the patient was at this point neither suitable for open AAA surgery nor endovascular treatment. His clinical condition worsened due to development of a systemic inflammatory response syndrome (SIRS) and resulted in death. The presented case demonstrates that a growing AAA can cause, besides severe complications like perforation or dissection, in some rare cases SSAP as a first complication.
\end{abstract}

Key Words: Abdominal aortic aneurysm, Pancreatitis, Systemic inflammatory response syndrome

\section{INTRODUCTION}

Abdominal aortic aneurysm (AAA) is a disease found especially among older patients that in most cases remains asymptomatic until unveiled during radiologic testing or physical examination for other reasons. ${ }^{[1]}$ First symptoms can be caused by growth of the aneurysm or rupture. The symp- tomatic non-ruptured AAA presents itself through back-, flank-, abdominal- or groin-pains and a pulsatile abdominal mass. ${ }^{[2]}$ Sudden severe pain is typically the consequence of ruptured AAA and can be accompanied by profound hemodynamic instability and eventually limb ischemia due to a thrombus or debris mobilisation from the aneurysm. ${ }^{[1,3,4]}$

\footnotetext{
*Correspondence: Alisan Kahraman, MD; Email: alisan.kahraman@uk-essen.de; Address: University Hospital Essen, Hufelandstr 55, Essen 45122, Germany.
} 
There are only few documented cases in literature of AAA that initially became symptomatic through complications caused by compression of flanking abdominal organs, in particular, causing acute pancreatitis. In opposition, acute pancreatitis can lead to arterial aneurysms due to enzymatic degradation of the arterial wall, which is a rare, but well known complication. ${ }^{[5-8]}$ However, first manifestation of acute pancreatitis caused by compression of pancreatic ducts due to a growth of arterial aneurysms, particularly AAA, remains a rarity. ${ }^{[8-10]}$

\section{CASE REPORT}

A 78-year-old man with known arterial hypertension, chronic obstructory pulmonary disease with cachexia, and vascular dementia was referred to our institution in August 2013 for further diagnostic staging and therapy of a cutaneous T-cell lymphoma, which had been confirmed by skin biopsies at the back and left upper leg (T3N0M0 B0, stadium IIB referring to the cutaneous lymphoma task force of the European organization of research and treatment of cancer $\left.{ }^{[11]}\right)$. During hospitalisation the patient became somnolent and presented elevated infection parameters (for c-reactive protein $5.9 \mathrm{mg} / \mathrm{dl}$ and for leukocytes $13.09 \mathrm{mg} / \mathrm{nl}$ ). We performed basic diagnostic testing when abdominal ultrasonography demonstrated a pulsating abdominal mass. The patient had no further complaints and showed no symptoms of pain at all. The following CT examination revealed a stretched pancreas and an underlying partial thrombosed juxtarenal abdominal aortic aneurysm extending distally from the origin of the superior mesenteric artery (SMA) to the aortic bifurcation. However, the SMA and the Truncus coeliacus had significant stenosis at their origins, but there were no signs of visceral malperfusion. The Ductus pancreaticus was dilated to $4 \mathrm{~mm}$ in the corpus (see Figure 1). There was no involvement of the Ductus segment located in the head of the pancreas, although pancreas head was deviated fronto-lateral caused by the underlying mural thrombus of the AAA (see Figure 2). There were no additional radiological findings of other occupying processes, signs of organ infiltration by the T-cell lymphoma or other causes of obstruction. No additional radiological signs of acute pancreatic inflammation, pancreatic oedema or necrotizing pancreatitis were present. Blood chemistry revealed elevated values of amylase up to $1,741(13-53) \mathrm{U} / \mathrm{ml}$ and lipase to 3,337.6 (5.6-51.3) $\mathrm{U} / \mathrm{ml}$ (see Table 1). The patient presented without further typical signs of acute pancreatitis and there was no elevation of liver enzymes or total serum bilirubin. The patient had no history of prior abdominal surgery or intestinal disease except gastroesophageal reflux, which has been treated with omeprazole $(20 \mathrm{mg} / \mathrm{dl})$. There were no identifiable risk factors indicating the likely development of pancreatic disease and the patient never had been jaundiced. The patient was taking enalapril $(10 \mathrm{mg} / \mathrm{dl})$ orally.

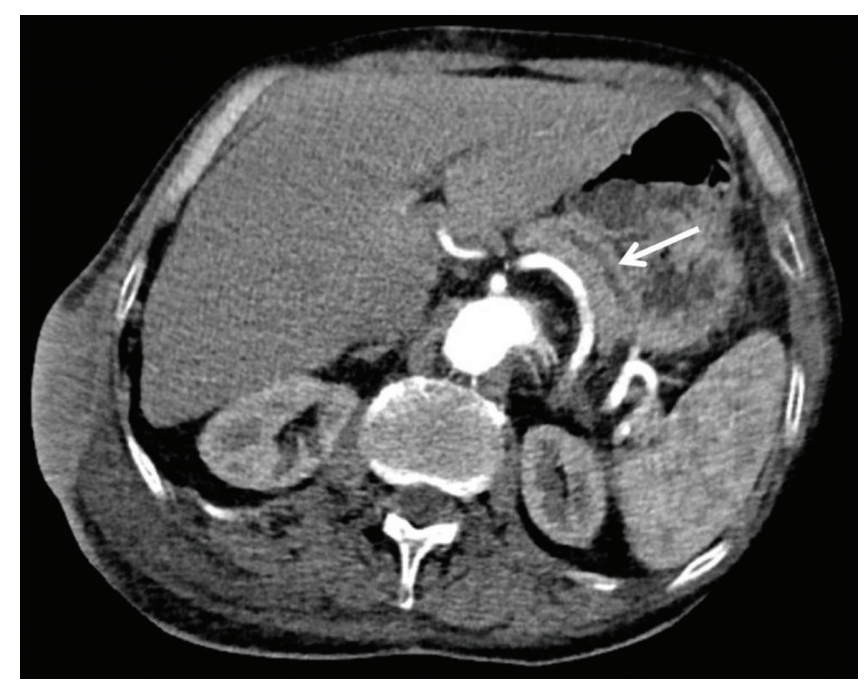

Figure 1. CT image demonstrating a slightly stretched pancreas with dilated pancreatic duct to $4 \mathrm{~mm}$ (arrow) and upper portions of the underlying partial thrombosed abdominal aortic aneurysm extending distally from the origin of the superior mesenteric artery (SMA) to the bifurcation with an external diameter of $79 \mathrm{~mm} \times 59 \mathrm{~mm}$

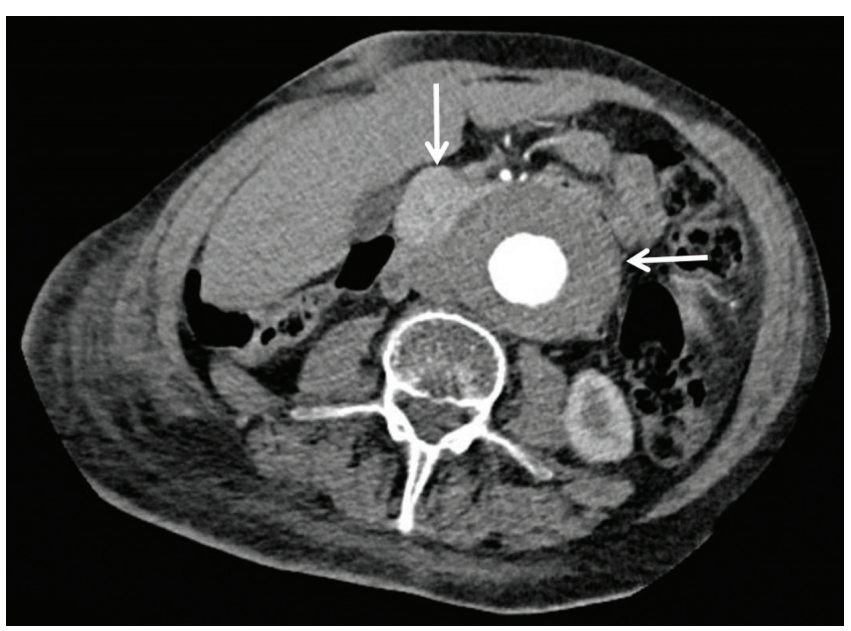

Figure 2. No involvement of the ductus segment located in the head of the pancreas (vertical arrow) was observed, although pancreas head was deviated fronto-lateral caused by the underlying mural thrombus of the AAA (horizontal arrow)

Although elevated values for amylase and lipase were regressive, clinical condition of the patient worsened with a general deterioration of health and the onset of hypotonia. The patient presented no fever at any time but required oxygen 
therapy from this point forward. Blood chemistry showed metabolic acidosis with elevated lactate (up to $8 \mathrm{mmol} / \mathrm{L}$ ). Despite calculated antibiotic treatment with sultamicilin (3 $\mathrm{g} / \mathrm{dl}$ intravenously) blood values increased for c-reactive protein to $11.2 \mathrm{mg} / \mathrm{dl}$ and for leukocytes to $16.75 \mathrm{mg} / \mathrm{nl}$, respectively. The patient was transferred to the intermediate care unit. Volume therapy with lactatet ringers's solution was initially sufficient to compensate the acidosis and stabilized blood pressure. Blood cultures were negative throughout the hospital stay. Due to persisting somnolence, hypotonia and elevated infection parameters the antibiotic medication was changed to meropenem (1 $\mathrm{g}$ intravenously). Despite supportive intensive care treatment the condition of the patient worsened and he showed signs of beginning renal failure. An additional $\mathrm{CT}$ examination demonstrated a slight increase of the AAA and a constantly dilated Ductus pancreaticus. Again there were no radiological signs of acute pancreatic inflammation, pancreatic oedema or necrotizing pancreatitis. Because of his advanced age, the progressive T-cell lymphoma, and his worsening clinical condition the patient was neither suitable for open AAA surgery nor endovascular treatment at this point. The developed SIRS resulted in multi-organ failure and caused death of the patient 10 days later.

Table 2. Overview of the literature

\begin{tabular}{|c|c|c|c|c|c|}
\hline Author/year & Age/gender & $\begin{array}{l}\text { Aneurysm } \\
\text { location }\end{array}$ & Obstruction location & Clinical symptoms & Treatment/Outcome \\
\hline Dickinson, WL/1891 & 28/male & Abdominal aorta & Common bile duct & $\begin{array}{l}\text { Obstructive jaundice and fatal } \\
\text { hemorrhage }\end{array}$ & None, patient died \\
\hline Chen, CY/1999 & 71/male & Abdominal aorta & Common bile duct & Epigastralgia, vomiting, fever & $\begin{array}{l}\text { Patient died after three recurrent } \\
\text { episodes }\end{array}$ \\
\hline Spinelli, GD/1982 & $71 /$ male & Abdominal aorta & Common bile duct & Jaundice, fever, abdominal pain & $\begin{array}{l}\text { Surgery: choledocho-duodenal } \\
\text { anastomosis, recovery }\end{array}$ \\
\hline Van Gossum, A/1982 & 76/female & Abdominal aorta & Lower common bile duct & $\begin{array}{l}\text { Oral bleeding and disseminated } \\
\text { intravascular coagulation }\end{array}$ & None \\
\hline Hashmonai, M/1981 & 73/male & Abdominal aorta & Pancreatic head & $\begin{array}{l}\text { Obstructive jaundice and } \\
\text { sudden abdominal pain }\end{array}$ & Surgery: open aortic aneurysm repair \\
\hline Liebermann, Da/1983 & $67 /$ male & Abdominal aorta & $\begin{array}{l}\text { Common bile duct, } \\
\text { pancreas and duodenum }\end{array}$ & $\begin{array}{l}\text { Jaundice, burning epigastric } \\
\text { pain }\end{array}$ & $\begin{array}{l}\text { Surgery: open aortic aneurysm repair, } \\
\text { postoperative septic shock and death }\end{array}$ \\
\hline Dohi, K/1984 & 69/female & Abdominal aorta & $\begin{array}{l}\text { Common bile duct and } \\
\text { duodenum }\end{array}$ & Obstructive jaundice & $\begin{array}{l}\text { Surgery: open aortic aneurysm repair, } \\
\text { recovery }\end{array}$ \\
\hline Van Someren, N/1993 & 87/female & Abdominal aorta & Common bile duct & $\begin{array}{l}\text { Right hypochondrial pain, } \\
\text { vomiting }\end{array}$ & Conservative, recovery \\
\hline Dorrucci, V/2001 & 87/female & Abdominal aorta & Common bile duct & Obstructive jaundice, backpain & $\begin{array}{l}\text { Surgery: open aortic aneurysm repair, } \\
\text { recovery }\end{array}$ \\
\hline Smith, AD/2002 & $84 /$ female & Abdominal aorta & Common bile duct & $\begin{array}{l}\text { Vague non-specific abdominal } \\
\text { discomfort, abnormal liver test }\end{array}$ & Conservative, symptoms recurrent \\
\hline Cowell, D/2010 & 80/female & Abdominal aorta & Lower bile duct & $\begin{array}{l}\text { Abdominal pain, } \\
\text { elevated liver enzymes }\end{array}$ & Conservative, symptoms recurrent \\
\hline Fukui, T/2012 & 88/female & Abdominal aorta & $\begin{array}{l}\text { Distal common bile duct, } \\
\text { pancreatic head and } \\
\text { duodenum }\end{array}$ & $\begin{array}{l}\text { Vague non-specific upper } \\
\text { abdominal discomfort }\end{array}$ & $\begin{array}{l}\text { Endovascular stent grafting of the } \\
\text { aortic aneurysm, complete recovery }\end{array}$ \\
\hline
\end{tabular}

\section{Discussion}

Acute pancreatitis is usually accompanied by severe clinical symptoms. Numerous conditions are known to induce acute
Table 1. Baseline demographic and biochemical characteristics of the patient

\begin{tabular}{lll}
\hline Laboratory Studies & September 2013 & Reference \\
\hline White blood cells & $13.09 \mathrm{~g} / \mathrm{nl}$ & $3.6-9.2 \mathrm{~g} / \mathrm{nl}$ \\
Hemoglobin & $11.9 \mathrm{~g} / \mathrm{dl}$ & $11.8-17.5 \mathrm{~g} / \mathrm{dl}$ \\
Platelets & $184 \mathrm{~g} / \mathrm{nl}$ & $140-320 \mathrm{~g} / \mathrm{nl}$ \\
Prothrombin time & $81 \%$ & $70 \%-130 \%$ \\
INR & 1.11 & \\
Calcium & $2.38 \mathrm{mmol} / \mathrm{L}$ & $2.08-2.62 \mathrm{mmol} / \mathrm{L}$ \\
Aspartat aminotransferase & $42 \mathrm{U} / \mathrm{L}$ & $0-50 \mathrm{U} / \mathrm{L}$ \\
Alanine aminotransferase & $22 \mathrm{U} / \mathrm{L}$ & $0-50 \mathrm{U} / \mathrm{L}$ \\
Total bilirubin & $0.5 \mathrm{mg} / \mathrm{ml}$ & $0.3-1.2 \mathrm{mg} / \mathrm{dl}$ \\
Total protein & $5.92 \mathrm{~g} / \mathrm{dl}$ & $6.4-8.3 \mathrm{~g} / \mathrm{dl}$ \\
$\gamma$-Glutamyl-transferase & $17 \mathrm{U} / \mathrm{L}$ & $0-55 \mathrm{U} / \mathrm{L}$ \\
Lactat dehydrogenase & $1,284 \mathrm{U} / \mathrm{L}$ & $100-247 \mathrm{U} / \mathrm{L}$ \\
Amylase & $1,741 \mathrm{U} / \mathrm{L}$ & $13-53 \mathrm{U} / \mathrm{L}$ \\
Lipase & $3,337.6 \mathrm{U} / \mathrm{L}$ & $5.6-51.3 \mathrm{U} / \mathrm{L}$ \\
Cratinine & $1.07 \mathrm{mg} / \mathrm{dl}$ & $0.9-1.3 \mathrm{mg} / \mathrm{dl}$ \\
Blood urea nitrogen & $24 \mathrm{mg} / \mathrm{dl}$ & $6-19.8 \mathrm{mg} / \mathrm{dl}$ \\
C-reactive protein & $5.9 \mathrm{mg} / \mathrm{dl}$ & $0-0.5 \mathrm{mg} / \mathrm{dl}$ \\
\hline
\end{tabular}

Note. Age: 78 years; Gender: Male; Race: Caucasian; Height: $165 \mathrm{~cm}$; Weight: $53 \mathrm{~kg}$; BMI: $19 \mathrm{~kg} / \mathrm{m}^{2}$.

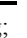


either caused by gallstones or result of malignant processes, usually of the pancreas itself. To our best knowledge there are only 12 cases according to literature (see Table 2) reporting aneurysms of the abdominal aorta as the cause for acute obstruction of the pancreatic duct or distal common bile duct. ${ }^{[12-23]}$ Also among radiological findings of uncommon types and causes of pancreatitis, aneurysms of the abdominal arteries, especially AAA, remain a rarity. ${ }^{[8]}$

According to the widely used Atlanta classification, our patient suffered from acute severe pancreatitis by presenting pulmonary insufficiency, hypotension and renal failure. Despite his poor clinical condition, he presented at no point typical clinical symptoms such as severe upper abdominal pain radiating to the back, nausea or vomiting. Cases of symptomatic acute pancreatitis due to compression of the distal common bile duct by a growing AAA, with sudden onset of severe symptoms, have been reported before. ${ }^{[13,15-17,22]}$ However, common bile duct compression by a growing AAA may also lead to episodes of recurrent jaundice ${ }^{[18,19]}$ with only mild and unspecific symptoms. ${ }^{[18,21]}$ Fukui et al. reported a case with unspecific abdominal symptoms and compression of the distal common bile duct with distension of the proximal bile and main pancreatic ducts in the body and tail of the pancreas by a growing AAA. ${ }^{[23]}$ The patient was treated successfully by endovascular stent grafting via the femoral artery and recovered completely.

However, due to the absence of typical clinical symptoms in our patient, diagnosis may have been delayed. At the time diagnosis was established, the clinical status of the patient had already worsened to a point where invasive treatment such as open surgical repair or endovascular treatment were no longer feasibly. In general, painless acute pancreatitis is an uncommon and rare finding and has been reported in coherence with sorafenib treatment, ${ }^{[24]}$ after renal transplantation, ${ }^{[25]}$ after assistive device implantation, ${ }^{[26]}$ as a rare complication of Legionnaires' disease ${ }^{[27]}$ and in one other case with panniculitis as the primary solitary manifestation. ${ }^{[28]}$

Our case is the first to best of our knowledge, where a growing AAA presented via a silent severe acute pancreatitis as the first clinical manifestation. Therefore, we suggest that also uncommon complications caused by a growing AAA should to be taken into consideration, especially in the elderly patient with pancreatitis. This may avoid crossing the line were potential treatment options are not feasibly any longer.

\section{REFERENCES}

[1] Upchurch GR, Schaub TA. Abdominal aortic aneurysm. Am Fam Physician. 2006; 73(7): 1198-204. PMid:16623206

[2] Tsuchie H, Miyakoshi N, Kasukawa Y, et al. High prevalence of abdominal aortic aneurysm in patients with chronic low back pain. Tohoku J. Exp. Med. 2013; 230: 83-6. PMid:23759898 http://dx.doi.org/10.1620/tjem.230.83

[3] Nigro G, Giovannacci L, Engelberger S. The challenge of posttraumatic thrombus embolization from abdominal aortic aneurysm causing acute limb ischemia. J Vasc Surg. 2011; 54: 840. PMid:21477964 http://dx.doi.org/10.1016/j.jvs.2011.01.051

[4] Baxter BT, McGee GS, Flinn WR. Distal embolisation as a presenting symptom of aortic aneurysms. Am J Surg. 1990; 160: 197. http://dx.doi.org/10.1016/S0002-9610(05)80306-X

[5] Skipworth J, Raptis D, Brennand D, et al. The management of multi-site, bleeding, visceral artery pseudoaneurysms, secondary to necrotising pancreatitis. Ann R Coll Surg Engl. 2009; 91(3): 255-8. PMid:19220939 http://dx.doi.org/10.1308/0035884 $09 \times 359295$

[6] Janczak D, Fiktus A, Pawlowski L, et al. Ruptured splenic artery aneurysm (SAA) as a complication of acute pancreatitis - case report. Pol Przegl Chir. 2012; 84(10): 551-4. PMid:23324371

[7] Puri A, Acharya $\mathrm{H}$, Tyagi S, et al. Pseudoaneurysm of the radial branch of the splenic artery with pancreatic pseudocyst in a child with recurrent acute pancreatitis: treatment with endovascular stent graft and cystogastrostomy. J Pediatr Surg. 2012; 47(5): 10125. PMid:22595592 http://dx. doi .org/10.1016/j . jpedsurg. 2012.02 .006

Published by Sciedu Press
[8] Shanbhogue AK, Fasih N, Surabhi VR, et al. A clinical and radiologic review of uncommon types and causes of pancreatitis. Radiographics. 2009; 29(4): 1003-26. PMid:19605653 http://dx.doi.org/10. $1148 / \mathrm{rg} \cdot 294085748$

[9] Swaroop VS, Chari ST, Clain JE. Severe acute pancreatits. JAMA. 2004; 291(23): 2865-8. PMid:15199038 http://dx.doi.org/10 $1001 /$ jama. 291.23 .2865

[10] Sondheimer FK, Steinberg I. Gastrointestinal manifestations of abdominal aortic aneurysms. Am J Roentgenol Radium Ther Nucl Med. 1964; 92: 1110-22. PMid:14236578

[11] Olsen E, Vonderheid E, Pimpinelli N, et al. Revision to teh staging and classification of mycosis fungoides and Sézary syndrome: a proposal of the International Society for Cutaneous Lymphomas (ISCL) and the cutaneous lymphoma task force of the European Organization of Research and Treatment of Cancer (EORTC). Blood. 2007; 110: 1713-1722. PMid:17540844 http://dx.doi.org/10.1182/blo od-2007-03-055749

[12] Dickinson WL. Aneurysm of abdominal aorta compressing common bile duct and rupturing into duodenum. Trans Pathol Soc. 1891; 42: 77-78.

[13] Chen CY, Lu CL, Chou YH, et al. Abdominal aortic aneurysm compression is probably responsible for the recurrent episodes of acute pancreatitis: case report. Hepatogastroenterology. 1999; 46(28): 2625-7. PMid: 10522053

[14] Spinelli GD, Kleinclaus DH, Wenger JJ, et al. Obstructive jaundice and abdominal aortic aneurysm: an ultrasonographic study. Radiology. 1982; 144: 872. PMid:7111739 http://dx.doi.org/10.11 48/radiology.144.4.7111739 
[15] Van Gossum A, Rubinstein M, Engelholm, et al. Common bile duct compression by an abdominal aortic aneurysm. Endoscopy. 1986; 18 : 69-70. PMid:3956442 http: //dx . doi .org/10.1055/s-2007-1 018332

[16] Hashmonai M, Stahl S, Schramek A. Rupture of an aortic abdominal aneurysm presenting as painful obstructive jaundice. J Cardiovasc Surg (Torino). 1981; 22: 187-189.

[17] Lieberman DA, Keeffe EB, Rahatzad, et al. Ruptured abdominal aortic aneurysm causing obstructive jaundice. Dig Dis Sci. 1983; 28: 8893. PMid:6822186 http://dx.doi.org/10.1007/BF01393366

[18] Dohi K, Fukuda Y, Nakagawa K, et al. A case of obstructive jaundice due to abdominal aneurysm compression. Hiroshima J Med Sci. 1984; 33: 819-823. PMid:6534936

[19] Van Someren N, Benson M, Jacomb-Hood J, et al. Aneurysmal dilation of the abdominal aorta: a rare cause of obstructive jaundice. Gastrointest Endosc. 1993; 39: 85-87. http://dx.doi.org/10 1016/S0016-5107 (93)70021-8

[20] Dorrucci V, Dusi R, Rombola G, et al. Contained rupture of an abdominal aortic aneurysm presenting as obstructive jaundice: report of a case. Surg Today. 2001; 31: 331-332. PMid:11321343 http://dx.doi.org/10.1007/s005950170154

[21] Smith AD, Mohammed F, Watson GM, et al. Common bile duct compression by an abdominal aortic aneurysm: an unusual cause of biliary tract dilatation. Eur J Gastroenterol Hepatol. 2002; 14: 767-769. PMid:12169986 http://dx.doi.org/10.1097/00042 737-200207000-00009
[22] Cowell D, Pover A, Buter A, et al. Education and Imaging. Hepatobiliary and pancreatic: bile duct dilatation caused by an aortic aneurysm. J Gastroenterol Hepatol. 2010; 25: 1467. PMid:20659243 http://dx.doi.org/10.1111/j.1440-1746.2010.06426.x

[23] Fukui T, Suzuki R, Sakaguchi Y, et al. Dilatation of the bile and pancreatic ducts due to compression by an unruptured abdominal aortic aneurysm (AAA): a case ameliorated by an endovascular stent grafting. Intern Med. 2012; 51: 2749-52. PMid:23037467 http://dx.doi.org/10.2169/internalmedicine.51.8294

[24] Kobayashi Y, Kanemitu T, Kamoto A, et al. Painless acute pancreatitis associated with sorafenib treatment: a case report. Med Oncol 2011; 28(2): 463-5. PMid:20300970 http://dx . doi .org/10.10 07/s12032-010-9479-2

[25] Siegal B, Simon D, Reiff A, et al. Silent pancreatitis following renal transplantation. Int Surg. 1982; 67(3): 279-80. PMid:6761296

[26] Swanson KE, Ward EM, Wolfsen HC. Painless pancreatitis after implantation of a biventricular assistive device. Transplant Proc. 2003; 35(4): 1546-8. http://dx.doi.org/10.1016/S0041-1345(03 ) 00443-3

[27] Kesavan CR, Pitchumoni CS, Marino WD. Acute painless pancreatitis as a rare complication of Legionnaires' disease. Am J Gastroenterol. 1993; 88(3): 468-9. PMid:8438870

[28] Agarwal MP, Giri S, Gandhi V, et al. Education and imaging gastrointestinal: a cutaneous clue to painless acute on chronic pancreatitis. J Gastroenterol Hepatol. 2012; 27(4): 842. PMid:22436060 http://dx.doi.org/10.1111/j.1440-1746.2012.07091.x 